Resumen por el autor, P. W. Whiting.

Estudios genéticos sobre la mariposa de la harina, Ephestia kühniella Zeller

Las nvestigaciones genéticas efectuadas con la mariposa de la harina, procedente del Mediterráneo, han demostrado la herencia de diversas variaciones de forma y color. Asi, por ejemplo, los defectos de los palpos labiales se heredan irregularmente. La lengua hendida se hereda como recesivo pero las mariposas que genéticamente contienen este factor aparecen normales somáticamente a causa de las condiciones del medio ambiente. El factor "oscuro," como indica su nombre, oscurece el área media de las alas anteriores y aclara la base y márgen externo. No se ha estudiado cuidadosamente pero depende probablemente de una diferencia de un solo factor con un heterozigoto intermedio y variable. El factor "sooty," S, ennegrece la base y márgen externo y aclara el área media, produciendo de este modo un efecto algo contrario al de "oscuro." Actúa como un dominante casi completo sobre el tipo, s; pero en cultivos que contienen individuos con el factor oscuro y otras variaciones menores, heredadas independientemente, presenta una inter-graduación completa con el tipo. El factor "negro," b, (cuerpo y alas) actúa como un recesivo simple y completo sobre el color gris típico, B. En la mariposa negra homozigótica, el color "sooty" presenta dominancia invertida actúando como un recesivo. Para denotar esta particularidad los símbolos del locus para sooty se han invertido, sS.bb. En las mariposas sooty-negras homozigóticas, SS.bb, el efecto dilutivo del factor sooty aparece en el área media. El índice diheterozigótico es: 9 sooty, 3 tipo, 1 sooty negra y 3 negras. El autor propone una hipótesis para explicar la distribución del pigmento en las alas, inversión de la domínancia, inter-graduación de los caracteres por los efectos invertidos de factores que complican los resultados, etc., la cual supone la existencia de una acción ondulatoria de un agente productor de color y otro inhibidor del mismo. Los caracteres estudiados no demuestran la existencia de ligamiento u otras complicaciones en el mecanismo hereditario.

Translation by José F. Nonidez Columbia University 


\title{
GENETIC STUDIES ON THE MEDITERRANEAN FLOUR-MOTH, EPHESTIA KÜHNIELLA ZELLER
}

\author{
P. W. WHITING \\ Zoological Laboratory of the University of Pennsylvania
}

ONE FIGURE AND TWO PLATES

\section{CONTENTS}

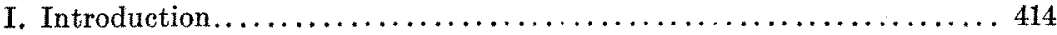

A. Distribution and taxonomy. ...................... 414

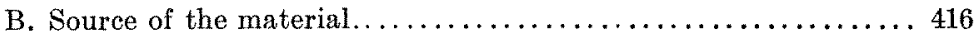

C. Technique................................ 417

II. Observations, experimental data, and conclusions............. 419

A. Description and origin of variations noted.............. 419

1. Description of variations....................419

a. Color............................ 419

b. Size $\ldots \ldots \ldots \ldots \ldots \ldots \ldots \ldots \ldots \ldots \ldots \ldots \ldots \ldots \ldots \ldots .419$

c. Leg spines......................... 419

d. Genitalia........................... 420

e. Mouth parts...................... 420

2. Analysis of original stocks................... 421

a. Bussey stock. Defective mouth parts........., 421

b. Lowell stock. Defective mouth parts and sooty base........................... 421

c. Calvert stock. Cleft tongue and sooty base....... 422

d. Washington stock. Defective mouth parts........ 422

$e$. Strain $A$ of Washington stock. Black color and dark mid-area ....................... 422

B. Tests for the hereditary nature of variations noted ......... 423

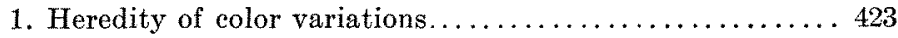

a. Black......................... 423

b. Dark mid-area...................... 423

c. Sooty base........................ 424

2. Heredity of oral defects...................... 424

a. Cleft tongue. The masking of a Mendelian difference by environment.................. 424

b. Defective palpi...................... 426

C. Tests for linkage of cleft, black, and sooty ............ 426

1. Free segregation of cleft and black.............. 427

2. Free segregation of cleft and sooty .............. 427

3. Apparent complications of black and sooty...........428 
D. Analysis of the gradations of sooty base ............... 428

E. Reversal of dominance of sooty by black.............. 430

III. Summary and general discussion ....................... 434

A. The masking of a Mendelian difference by environment....... 434

B. Reversal of dominance.......................... 435

C. Analysis of a case of continuous variation............... 435

D. The physiology of color production ................. 436

\section{INTRODUCTION}

\section{A. Distribution and taxonomy}

The Mediterranean flour-moth, Ephestia Kühniella Zeller, is widely distributed and very destructive to stored cereals. It was noticed in Paris in 1840 and in Constantinople in 1872. An outbreak of the pest occurred at Halle, Germany, in 1877, where it was supposed to have been introduced with some American wheat. The American origin was assumed by European writers for a number of years, but it is probable that the insect was rather widely distributed in Europe for some time, being noticed only when it became especially abundant and troublesome. It was not officially reported in America until 1889 (Canada).

The insect belongs to the subfamily Phycitinae of the large family Pyralidae. Its nearest important relatives are the driedcurrant moth, Ephestia cautella Walker, the chocolate moth, Ephestia elutella Hübner, and the Indian-meal moth, Plodia interpunctella Hübner.

In June, 1877, Professor Kühn, of the university at Halle, sent a number of specimens to Zeller whose description appeared in 1879. It is thought advisable to quote the original description of the moth since the taxonomic type agrees with the genetic type as treated in the present paper. Color characters with which this paper is concerned have been placed in italics in Zeller's description quoted below.

Major, alis elongatis, ant. cinereis, strigis 2 obsoletis dilutioribus, obscurius marginatis: priore ante medium posita, oblique, subserrata, posteriore superne fracta, margini postico nigro-punctato admota, puncto venae transversae nigro gemino saepe in strigulam mutato, umbra subfasciata ab eo introrsus ad dorsum demissa; post. albidis, subhyalinis, ramis venae medianae griseis. $0^{7} q$ 
Grösse der Homeos. nimbella. Kopf und Rückenschild von dem lichten Grau der Vorderflügel. Stirn gerundet. Taster aufgekrümmt, anliegend, hellgrau, an den Seiten des 2. und 3. Gliedes ausser an der Spitze schwärzlich. Sauger stark, auf dem Rücken hellgrau beschuppt. Fühler grau, undeutlich geringelt. Hinterleib heller als der Thorax, mit weisslichem Bauch. Männlicher Analbusch schmutzig weissgelblich; Genitalzangen ansehnlich, länglich löffelförmig, mit gelblichen, verlängerten Schuppen reichlich bekleidet. Legestachel weisslichgelb, lang hervorstehend. Beine grau; Füsse aussen dunkler mit weisslichen Spitzen der Glieder; Hinterschienen zusammengedrückt, am Ende durch Haarschuppen erweitert; vor der Spitze aussen schwärzlich.

Vorderfügel über 5 und bis fast $6^{\prime \prime \prime}$ lang (bei einem o nur $4^{\prime \prime \prime}$ ), gestreckt, mit sanft gebogenem, nach hinten stärker convexem Vorderrand, wegen der Fransen ungefähr rechtwinkliger Spitze und sanft convexem Hinterrand. Grundfarbe hellgrau ohne andere beigemischte Farbe. Der erste Querstreifen, in der Mitte zwischen Basis und Queraderpunkt, ist schräg, etwas nach aussen gebogen, undeutlich sägezähnig, auf der Subdorsale mit scharfem, einspringendem Winkel, heller als die Grundfarbe, auswärts gewöhnlich nur bis zur Medianader breit schwärslich gesäumt, darunter im Subdorsalwinkel mit einer deutlichen schwarzen Ausfüllung. Die zwei schwarzen, fast senkrecht über einander stehenden Queraderpunkte (der untere grösser und oft längsstrichformig) vereinigen sich oft zu einem oben verdünnten Querstrich; von dessen unterem Ende oder dem unteren Punkt läuft ein etwas breiter, nicht immer deutlicher, schwarzer Schattenstreif einwärts zur Mitte des Innenrandes. Der zweite helle Querstreifen, dem Hinterrande näher als der Querader und jenem parallel, macht in seinem obern Drittel einen scharfen, nach aussen offenen Winkel; er ist etwas sägesähnig und auf beiden Seiten, auf der hintern vollständiger als auf der vordern, mit schwarzen Aderstrichen gesäumt. Vor dem mit groben, schwarzen Punkten eingefassten Hinterrande sind die Längsadern oft fast alle schwarz. Fransen einfarbig hellgrau.

Hinterflügel spitz, weisslich, durchscheinend, mit verloschener, grauer Hinterrandlinie, welche sich um die Spitze bis in den Vorderrand zieht; auch die Medianader mit ihren Aesten ist grau. Basis beim $\sigma^{7}$ ohne Haarbusch. Fransen weisslich, an der Wurzel mit feiner, gelblicher Linie durchzogen. Haare des Abdominalrandes oft sehr blassgelblich.

Unterseite der Vorderflügel einfarbig, schimmernd hellgrau, ganz an der Wurzel mit einigen einwärts verlängerten Haarschuppen des Vorderrandes. Hinterflügel weisslich, am ganzen Vorderrand bis zur Subcostale lichtgrau.

Beide Geschlechter sind wenig verschieden; nur ist das $\$$ gewöhnlich das schärfer gezeichnete.

In figure $m$ is shown a specimen which closely approximates the type as described by Zeller. It is probable that his speci- 
mens may have been a little lighter than the average of my own, for it was the transverse light bands ("strigis 2 obsoletis dilutioribus" and "Der erste Querstreifen,... heller als die Grundfarbe... Der zweite helle Querstreifen,") rather than the dark, that appeared especially to strike his attention. In general later descriptions emphasize the transverse dark bands. For example, Miss Ormerod ('89) describes the fore-wings as "pale gray with darker transverse markings."

The typical ground color of the fore-wings is gray or ashy ("ant. cinereis" and "Grundfarbe hellgrau ohne andere beigemischte Farbe,") in my specimens and according to all descriptions available, although Riley ('89) mistakenly says "in the typical specimens raised by Zeller the ground color is pure yellow or nearly brownish."

I have not been able to correlate with sex any color character such as mentioned by Zeller. The markings of both sexes appear to me to be equally distinct.

Numerous articles concerned chiefly with the economic importance of the moth are referred to in the bibliographies of American economic entomology by Nathan Banks.

The experiments described in this paper have been carried on by aid of a Harrison Research Fellowship of the University of Pennsylvania. My thanks are due to the members of the Zoological Department for their interest and suggestions.

\section{B. Source of the material}

The moths used in the experiments belonged to the following stocks:

Bussey stock. On January 28, 1915, five adult moths were placed in a glass jar 4 inches in diameter and 5 inches high with tin cover screwed down tight. The cover must have admitted but slight circulation of air. The jar was half filled with white flour. It was set in a dark closet at the Bussey Institution, Boston, Massachusetts, and was not disturbed until June 2, 1916. At that time there were many insects in all stages of development. It is probable that the culture might have lasted much longer as the flour was by no means exhausted. 
Lowell stock. A box of "Cream of Wheat" from Lowell, Massachusetts, was found in July, 1916, to be infested.

Calvert slock. A large tin box of flour heavily infested was given me by Professor Calvert in the fall of 1916.

Washington stock. A culture was obtained from the Bureau of Entomology, Washington, D. C., in June, 1916.

Strain A of Washington stock. A pair of moths was isolated from the Washington stock on July 11, 1916. The female was probably not virgin. A mass culture was made from the progeny.

During July and the first part of August, 1916, the moths were bred and studied at the Marine Biological Laboratory, Woods Hole, Massachusetts. From then until the end of September they were left in mass cultures. The results described below are from matings made at the Zoological Laboratory of the University of Pennsylvania.

\section{Technique}

Various methods of rearing the moths have been tried. It has been found convenient to use glass candy jars with an inside measurement of $4 \frac{1}{2}$ inches in height by 4 inches in diameter. A small amount of cereal is placed in the jar and the etherized moths are set upon this. If progeny are produced, as may be easily determined by the appearance of webs, more cereal is added.

Pupation normally occurs in silken tubes spun in the cereal, but overcrowding or lack of food sometimes causes the caterpillars to wander. The moths emerge and rest upon the glass. They do not fly unless disturbed, so that it is an easy matter to collect them in a shell vial. After several moths have been thus secured they are turned into a wide-mouthed bottle containing ether fumes. The etherized moths may be studied under a binocular and sorted out for recording and pairing.

Once fertile eggs have been obtained from a pair, there is little difficulty in rearing the larvae, The jar has but to be set in a warm, humid place. The adult moths are, however, extremely sensitive to environmental conditions. Mating apparently occurs 
at any ordinary temperature or humidity, but the females are very perverse about egg-laying. The proper conditions have not yet been determined, and consequently the results obtained have been a chance selection from a very large number of pairs set. Usually not more than 5 or 10 per cent of the pairs prove fertile, but I have occasionally had as good a ratio as 50, 60 , or even 70 per cent. The most frequent condition of infertility is the failure of the female to oviposit. Examination has been made of a large number of such females. The abdomens have been found to be filled with large eggs apparently mature and normal. Another peculiar condition is the failure of the eggs to hatch unless almost all the eggs are laid. It has been found that if the female retains a large proportion of her eggs, the eggs which are laid do not hatch. The pairs have in this case frequently been observed to mate, but it is possible, nevertheless, that the eggs have not been fertilized. Records are being kept of all these conditions and further studies will be made.

If conditions are warm and humid, moths begin eclosing five weeks after the parents have been isolated. Considerable variation obtains in rate of development of the larvae from any one pair, so that moths of one fraternity are sometimes eclosing over a period of one, two or even three months. It is probable that this tends to compensate for the high sterility, for if conditions are not favorable for oviposition at one time they may be at another. There is thus no difficulty in keeping mass cultures. Even extreme reduction in food with consequent reduction in size of the moths does not exterminate them. Despite the extreme sensitiveness of the adults, the species is adapted to tide over very unfavorable conditions.

Since mating takes place as soon as the wings are dry, females are counted as virgin only when found in cultures before a male has emerged. 
II. OBSERVATIONS, EXPERIMENTAL DATA, AND CONCLUSIONS

\section{A. Description and origin of variations noted}

1. Description of variations. a. Color. During the studies at Woods Hole and later the moths were examined for variations. It was soon noticed that there were many minor differences in wing color and pattern and that these appeared to be hereditary. Certain cultures produced moths darker than others, while some had the transverse bands of the wings very well marked. These differences persisted regardless of the nature of the food.

A few color variations were very well marked. The variety shown in figure $n$ has been called 'sooty base' or 'sooty.' The base of the primaries is black and the outer margin is much darkened. There is also a decided tendency for the intermediate area to be lighter than in the type. The factor producing this variation, $S$, proves dominant to type.

Another variation tends to darken the mid-area of the primaries, and possibly to lighten the base and outer margin. It has not as yet been studied satisfactorily. In some specimens it is very pronounced, but in others it grades into type. It is of interest because it has an effect the reverse of sooty base. It has been called 'Dark mid-area' or 'Dark.'

A black variation, acting as a simple recessive, $b$, is shown in figure $o$. The upper side of the primaries is black. The upper side of the secondaries is slightly darkened. The under side of the wings is light gray or white as in type, but some black appears along the costal margin. The legs and body are black or gray.

The homozygous sooty black, SS.bb, is shown in figure $p$.

$b$. Size. Variations in size are probably due to lack of suffcient food, since small moths have come out of certain crowded cultures. When virgin matings of these were made they produced moths of normal size.

c. Leg spines. Two spines occur at the tips of both the middle and the hind tibiae and two occur in the middle of the hind tibiae. They were studied in many hundreds of moths from 
mass cultures and individual matings. The number was always constant, and only slight variation occurred in length and divergence.

$d$. Genitalia. No secondary sexual characters could be found. The sexes may be readily distinguished, however, by the claspers of the male, as shown in figure $b$, and the ovipositor of the female, as shown in figure $e$. Occasionally a moth was found that had peculiar genitalia. Examination showed that these were males in which the claspers were shortened, twisted, or lacking. Internal sexual organs were apparently normal and spermatozoa were present in all.

e. Mouth parts. The adult moths do not feed. The mouth parts consist of the tongue, which is formed by the maxillae; the maxillary palpi, which are small and inconspicuous; and the three-jointed labial palpi, which conceal the maxillary palpi. The normal condition of the mouth parts is shown in figures $c$ and $f$. Many variations were observed in the tongue and in the labial palpi. The latter will be referred to hereafter as the palpi.

Figure $a$ shows a condition in which the palpi are fused in the median plane. The joints of each are fused with the corresponding joints of the other, so that there results a large flat threejointed median palpus. The tongue arises from the normal position above the insertion of the palpus and appears to be normal in every way. Its coil is pushed aside by the palpus. Figure $d$ shows a condition in which the palpi are asymmetrical. The two terminal joints of the left are lacking. The right is normal. Figure $l$ shows a condition in which the palpi are both shortened symmetrically. All sorts of variations in the palpi may occur, due to loss or shortening of the joints.

The tongue may be lacking altogether, as shown in figures $j$ and $k$. This variation occurred in some of the mass cultures early in the work. Much variation occurs also in length. The elements of the tongue, maxillae, which are normally united to form a tube, may be separated to any extent. The separation may occur at the tip only or from the tip any distance towards the base. In some cases also the basal or middle part may be 
divided while the distal part is normal. Failure of the maxillae to unite is apparently due to malformation.

Figure $g$ shows a condition in which the palpi are very small, the tongue is cleft to the base and a short distance from the base the elements diverge laterally. In figure $h$ the palpi are normal; the maxillae are separated distally. Occasionally a moth fails to shed the pupal covering of the head. It may otherwise be quite normal. Figure $i$ illustrates this, showing a ventral view in which also the maxillae are separated and coiled up at the sides.

Other variations are swellings on the tongue or antennae, straight tongue and scaleless areas on wings.

2. Analysis of original stocks. Summaries of the earlier results will be given in order to show the origin of the variations studied.

a. Bussey stock. Defective mouth parts. Nine non-virgin type females from the Bussey stock, when isolated, produced 841 type, 448 males and 393 females; 6 with defective palpi, 2 males and 4 females; 5 with deformed tongue, 2 males and 3 females; and one male with defective genitalia. Defects of palpi, tongue, and male genitalia, therefore, occur in the Bussey stock.

Twenty virgin females from the Bussey stock were paired with males, either from the Bussey, the Lowell, or the Washington stock. They produced 473 type, 255 males and 218 females; 3 with defective palpi, 1 male and 2 females, and 1 female with cleft tongue. Each of these abnormalities occurred among the offspring of a different mating, so that no significant Mendelian ratio appeared.

$b$. Lowell stock. Defective mouth parts and sooty base. Ten non-virgin type females from the Lowell stock, when isolated, produced 917 type, 452 males and 465 females; 24 with defective palpi, 13 males and 11 females; 7 with deformed tongue, 4 males and 3 females. Defects in palpi and tongue therefore occur in the Lowell stock as in the Bussey stock.

A pair of type produced 55 type, 25 males and 30 females; and 19 with cleft tongue, 9 males and 10 females. Another similar mating produced 27 type, 17 males and 10 females, and 8 with cleft tongue, 4 males and 4 females. This amounts to 
82 type and 27 with cleft tongue, suggesting that the latter may carry a factor acting as a simple recessive.

Among the moths of this stock were also noticed several of the sooty base variety (figure $n$ ). A pair of these produced 2 sooty, 1 male and 1 female, and 1 type, a female. This indicates that sooty may be dominant to type.

c. Calvert stock. Cleft tongue and sooty base. The moths of the Calvert stock were rather light in color. Some of them had wings with sooty base.

Two non-virgin females produced 101 moths with normal mouth parts and 2 with defective palpi. A sooty male was paired with a type female whose virginity was not certain. There were produced 7 type and 6 sooty. A pair of these type moths produced 9 type and 2 with cleft tongue, suggesting again the recessive character of cleft. The Calvert stock is of interest as it is the source of the factor for sooty base used in later experiments.

d. Washington stock. Defective mouth parts. Sixteen nonvirgin females from the Washington stock, when isolated, produced 1523 type, 744 males and 779 females; 11 with defective palpi, 7 males and 4 females; 3 with deformed tongue, 2 males and 1 female, and 1 female with defective palpi and deformed tongue.

Two other non-virgin females were isolated from a fraternity consisting of 44 moths with normal mouth parts. One of these produced 163 type, 85 males and 78 females; 7 with cleft tongue; 5 males and 2 females, and 2 with defective palpi, 1 male and 1 female. The other produced 116 type, 54 males and 62 females, and 40 with cleft tongue, 26 males and 14 females, thus closely approximating the Mendelian three to one ratio. A pair of these moths with cleft tongue produced 2 males and 1 female, all having cleft tongue. This furnishes additional evidence that cleft depends upon a recessive factor.

$e$. Strain A of Washington stock. Black color and dark midarea. On October 1, 1916, two males and four non-virgin females of typical color from strain A of Washington stock were isolated in a fresh culture. From December 1 to December 14 there 
emerged 105 males and 120 females of typical color, and 1 male, typical in color but with deformed genitalia. There also appeared for the first time 43 black moths, 18 males and 25 females. The factor for black was probably carried as a recessive by the Washington stock.

In later generations bred from this strain there appeared moths with dark mid-area.

\section{$B$. Tests for the hereditary nature of variations noted}

1. Heredity of color variations. a. Black. Summaries of all the results involving black will be given here whether or not other variations entered into the crosses. The recessive nature of black is demonstrated without question.

Fifteen pairs of homozygous gray by black produced 1099 gray. Dominance was complete.

Nineteen pairs of heterozygous gray by black produced 494 gray and 429 black. The deficiency of black below the expected one to one ratio is to be noted.

Three pairs of black produced 114 black indicating that black breeds true.

Fifteen pairs and two mass cultures of heterozygous gray produced 3353 gray to 969 black where 3241.5 to 1080.5 is to be expected. Again the deficiency of black is to be noted.

In cultures segregating gray and black there was considerable variation in ratios. This variation was so extreme in some cases that it is probable that disturbing causes such as lethal factors may have been acting.

$b$. Dark mid-area. It has not as yet been possible in all cases to separate moths of the dark mid-area variety from type. The gradation appears to be continuous. In some specimens the character is very pronounced. It is carried by black where it may sometimes be seen as a 'ghost pattern.'

A mating of a black male by a dark female and three matings of dark males by black females produced 126 gray and 118 black, which is very close to the one to one ratio expected from heterozygote by recessive. The grays graded from dark to type. 
A pair of dark produced 73 gray and 23 black, which is close to the three to one ratio expected from heterozygote by heterozygote. Again the grays showed much gradation between dark and type.

Another pair of dark produced 13 dark in which the character was very pronounced showing no gradation toward type.

A black male paired with a type female produced 14 gray grading from type to dark and 14 black.

Another pairing of black male by type female produced 24 gray, all of which showed the dark mid-area. In these two matings dark was evidently introduced with black.

c. Sooty base. Sooty base acts as a simple dominant to type, but its separation from type is sometimes rendered difficult by the presence of dark mid-area and other variations. This is more fully considered in another section. Only those fraternities in which the distinction from type was clear are here summarized.

Three pairs of homozygous sooty by type produced 430 sooty. Dominance was practically, although not quite, complete.

Two pairs of sooty produced 42 sooty.

Six pairs of heterozygous sooty by type produced 77 sooty and 93 type. The deficiency of sooty below the one to one ratio is to be noted.

Thirty-eight pairs of heterozygous sooty produced 1627 sooty to 615 type where 1681.5 to 560.5 is to be expected. Again the deficiency of sooty is to be noted.

No significant variation in ratios in cultures segregating sooty and type could be found. This is in marked contrast to the condition noted in regard to black.

2. Heredity of oral defects. a. Cleft tongue. The masking of a Mendelian difference by environment. The appearance of cleft tongue is much complicated by environmental conditions. Certain strains never throw cleft, while in others cleft occurs in variable ratios. It has been noticed that fraternities containing moths with cleft tongue show cleft emerging in large numbers at certain times and scarcely at all at others. The cultures have been shifted from humid to comparatively dry conditions and 
the appearance of cleft seems to be correlated with drying out. It has also been noticed that when few cleft appeared, the tongues were but slightly cleft.

Six pairs of normal produced 307 normal and 24 cleft, a few cleft appearing in each fraternity. Conditions were rather variable as regards humidity.

Three fraternities from normal parents were reared under dry conditions. They consisted of 55 normal and 19 cleft; 27 normal and 8 cleft, and 116 normal and 40 cleft, respectively. The cleft showed tongues cleft practically to base. Pairings were made of cleft from the last fraternity, but conditions were extremely dry and only one pair produced offspring, 3 moths with tongue cleft to base. Results indicate that we have here a recessive gene which expresses itself only under more or less arid conditions. The three fraternities reared from normal under dry conditions, when summarized, show 198 normal to 67 cleft, very close to 198.75 to 66.25 , the monohybrid expectation.

Two pairings of normal by deeply cleft produced under moderately dry conditions 95 and 89 normal, respectively. Moths from the former fraternity produced 262 normal to 51 cleft and moths from the latter fraternity produced 789 normal to 114 cleft. Conditions were somewhat variable during the rearing and eclosion of these $F_{2}$ moths. When summarized there were 1051 normal to 165 cleft. The expectation from a monohybrid cross would be 912 to 304, which shows that cleft apparently falls below expectation.

In the later course of the work a very high humidity was maintained. Under these conditions a pairing of a normal by a cleft from the segregating generation summarized above produced 148 normal to 11 cleft. Since one of the parents was cleft and cleft appeared among the progeny we would expect to have a one to one ratio, the ratio from heterozygote by recessive. The deficiency of cleft may be explained by the high humidity. Under these conditions four pairs of cleft by cleft produced 134 normal and only 12 cleft.

The irregular appearance of cleft may then be explained by the effect of environment. Further work is desirable to give added corroboration of this theory. 
b. Defective palpi. Defects in the palpi are likewise hereditary, but irregular in appearance.

A pair of moths both of which had defective palpi produced 48 moths with normal palpi.

A pairing of a normal male with a female having both palpi small and a pairing of a male having both palpi small with a normal female produced 189 normal and 12 cleft. No defects in palpi appeared.

A cleft male paired with a normal female produced 142 normal, 77 males and 65 females; 5 cleft, 2 males $(1$ with defective genitalia) and 3 females; 6 with defective palpi ( 3 of which had both short), 4 males and 2 females, and 6 with tongue cleft to base and palpi both short, 3 males and 3 females. There were 5 with cleft tongue but normal palpi, 6 with normal tongue but defective palpi, and 6 with cleft tongue and defective palpi. The correlation of defects in palpi with defects in tongue is unusual. Moreover, the shortening of both palpi rather than asymmetry is not the usual condition, but is here seen in 9, at least, of the 12 individuals with defective palpi.

Many large fraternities bred from normal had a very few moths with defective palpi, while many others showed none at all. The heredity of defects in palpi appears to be rather complicated. It has as yet been impossible to correlate the condition with any environmental effect.

\section{Tests for linkage of cleft, black, and sooty}

Two black females with deeply cleft tongue were selected from the black-producing cultures. One was paired with a gray normal male from the same culture from which she was taken. There were produced 95 gray normal. The pair was recorded as (105). The other black cleft female was paired with a gray sooty moth with normal tongue from the Calvert stock. There were produced 89 gray normal. Records were not kept in reference to sooty. The pair was recorded as (109).

The data given in the remainder of this paper deals with the descendants of pairs (105) (type male by black cleft female) and (109) (sooty male by black cleft female). 
1. Free segregation of cleft and black. The $\mathrm{F}_{2}$ generation from (105) consisted of 204 type, 58 black, 36 cleft, and 15 black cleft. There are 240 gray to 73 black, the expectation being 234 to 78 . There is thus no appreciable deficiency of black. There are 262 normal to 51 cleft, the expectation being 234 to 78 . There is thus deficiency of cleft. Among the normal there are 204 gray to 58 black, the expectation being 196.5 to 65.5 . Among the cleft there are 36 gray to 15 black, the expectation being 38.25 to 12.75 . The deviation from expectation is not enough to indicate linkage.

The $\mathrm{F}_{2}$ generation from (109) consisted of 599 type, 309 males and 290 females; 190 black, 95 males and 95 females; 87 cleft, 41 males and 46 females, and 27 black cleft, 12 males and 15 females. The summary shows 686 gray to 217 black and 789 normal to 114 cleft, the expectation being 677 to 226 in each case. There is obviously a considerable deficiency of cleft, while black agrees closely with expectation. It may be readily observed that there is no evidence of linkage between cleft and black.

Summarizing the $\mathrm{F}_{2}$ generations from matings (105) and (109), there are 803 gray, 248 black, 123 cleft, and 42 black cleft. There are 926 gray to 290 black and 1051 normal to 165 cleft. The expectation in either case would be 912 to 304 . There is clearly, then, a great deficiency of cleft. Among the normal there are 803 gray to 248 black where the expectation is 788 to 263 and among the cleft there are 123 gray to 42 black where the expectation is 124 to 41 . There is, then, no evidence of linkage between cleft and black.

2. Free segregation of cleft and sooty. Sooty base showed in a large proport on of the offspring of pair (109), but while very pronounced in some individuals it graded into type in others. This gradation was due in large part at least to the presence of dark mid-area. The moths were classified, however, in a more or less arbitrary manner in relation to this character. The progeny of pair (109) may have been of mixed composition as regards sooty, since the male parent may have been heterozygous. The $\mathrm{F}_{2}$ generation showed cleft distributed apparently without reference to sooty. If complete linkage occurred between cleft 
and sooty and if cleft is recessive as the $F_{1}$ generation apparently indicates, no cleft sooty should appear in $F_{2}$. If the linkage was partial the ratio of sooty to type should be higher than that of cleft sooty to cleft. Considering only the gray, since black introduces a further complication, which is entirely explained below, there were 249 sooty to 350 type, or 71 per cent; and 34 cleft sooty to 53 cleft, or 68 per cent. The difference between the ratios is not great enough to be significant. Although the classification was admittedly arbitrary as regards sooty, any error would not affect its relation to cleft. It may therefore be concluded that no linkage appears between cleft and sooty.

3. Apparent complications of black and sooty. In the black moths of the $\mathrm{F}_{2}$ generation from pair (109) accurate separation of sooty and non-sooty was uncertain as in the gray. It has been possible to test for linkage of cleft with sooty and with black. As regards relations between black and sooty, however, complications arise since the character affected is the same, namely, the color of the wings. If the classification were not disturbed by this fact and if no linkage existed, the ratio of sooty to type should equal the ratio of sooty black to black. There are recorded 283 sooty, 403 type, 19 sooty black, and 198 black. This gives 70.2 per cent as the ratio of sooty to type and only 9.6 per cent as the ratio of sooty black to black. It is evident from a comparison of these two ratios that there is either close linkage between sooty and black or else disturbance in dominance. Results recorded below prove that the latter is the case.

\section{Analysis of the gradations of sooty base}

It will be recalled that the variation called dark mid-area has an effect somewhat the reverse of sooty base. Dark mid-area appeared in many moths of the $F_{2}$ generation from (109) and doubtless accounts very largely for the difficulty in distinguishing sooty from type.

A pair of moths in which the primaries had rather dark bases and which were probably sooty with dark mid-area produced 72 sooty, 77 type, and 10 that were intergrading between sooty 
and type. The ratio appears like that produced by the crossing of a heterozygous dominant with a recessive but with some difficulty in classifying certain of the individuals. A pair of definitely sooty moths from this fraternity which probably lacked dark mid-area produced 30 definitely sooty and 6 definitely type.

A type male paired with a sooty female produced 25 sooty, 10 males and 15 females; 17 type, 10 males and 7 females, and 6 moths of intermediate appearance, 3 males and 3 females. A pair of these sooty moths produced a fraternity of 28 males and 30 females among which the gradation from sooty to type was so continuous that I found it impossible to make any good separation. A pair of these that showed rather dark wing-base produced a fraternity of 15 males and 14 females showing gradation. A pair of the type moths from the original fraternity produced 52 moths of typical color and these produced in the next generation 105 of similar character. It is possible then to extract type from an intergrading stock.

A pair of type moths produced 36 males and 38 females which showed considerable variability in the pigmentation of the base of the wings. None of them were dark enough to be called sooty, however. A pair of moths having wings with rather dark bases were selected and produced progeny that were classified as type, 10 males and 8 females, and moths with rather dark wing-base, 4 males and 6 females. The gradation was really continuous, but the evidence shows that the tendency toward darkening of the wing-base is hereditary. Such a tendency, occurring in a culture that is segregating sooty as well, would be very confusing. It appears, then, that a hereditary tendency to darken the base of the wing, as well as the variation known as dark midarea, may tend to obscure the distinction between sooty and type.

In the fraternities discussed below, the distinction between sooty and type was perfectly clear, indicating that the confusing factors were not present.

A sooty male paired with a type sister produced 111 sooty, 53 males and 58 females. Heterozygous $\mathrm{F}_{1}$ moths when paired produced 134 sooty, 61 males and 73 females, and 70 type, 35 males and 35 females, the expectation being 153 to 51 . 
A type male paired with a sooty female produced 12 sooty, 6 males and 6 females, and 7 type, 4 males and 3 females. A pair of these sooty produced 26 sooty, 10 males and 16 females, and 9 type, 5 males and 4 females. A sooty male from the same fraternity was paired with one of his type sisters. They produced 16 sooty and 20 type.

A black male paired with a sooty female produced 6 sooty and 8 type showing dominance of gray over black and segregation of sooty and type.

A type male paired with a sooty female produced 11 sooty, 17 type, and 1 black, which is close to expectation as regards sooty, but somewhat aberrant as regards black.

Two cultures of heterozygous sooty produced 124 sooty and 40 type, very close to the expected 3 to 1 ratio.

A sooty male paired with two sooty females produced 42 sooty.

Sooty is then a character which segregates sharply from type when once the complicating factors have been eliminated.

\section{E. Reversal of dominance of sooty by black}

A sooty male paired (125) with a black female from the same culture produced 129 sooty, 66 males (one with defective genitalia) and 63 females. The cross may be represented, SS.BB $\times$ ss.bb. Six pairs of the sooty progeny, Ss.Bb. produced offspring as shown in table 1.

TABLE 1

\begin{tabular}{|c|c|c|c|c|c|c|c|c|}
\hline \multirow{3}{*}{$\begin{array}{l}\text { COMPOSTTION } \\
\text { OF CULTURE. }\end{array}$} & \multicolumn{8}{|c|}{ OFFSPRING } \\
\hline & \multicolumn{2}{|c|}{ Sooty } & \multicolumn{2}{|c|}{ Type } & \multicolumn{2}{|c|}{ Sooty black } & \multicolumn{2}{|c|}{ Black } \\
\hline & $0^{x}$ & $q$ & $0^{\pi}$ & q & $0^{7}$ & 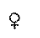 & $0^{\pi}$ & $\%$ \\
\hline $10 \times 19$ & 7 & 9 & 3 & 0 & 0 & 1 & 0 & 3 \\
\hline $10^{7} \times 1$ 우 & 1.8 & 25 & 3 & 8 & 0 & 0 & 4 & 5 \\
\hline $10^{7} \times 1$ \% & 23 & 29 & 10 & 11. & 1 & 2 & 8 & 9 \\
\hline $10^{\pi} \times 1 \%$ & 13 & 20 & 2 & 8 & 4 & 2 & 0 & 3 \\
\hline $10^{7} \times 19$ & 15 & 22 & 9 & 6 & 2 & 0 & 4 & 6 \\
\hline $30^{7} 0^{7} \times 1 \%$ & 20 & 17 & 6 & 12 & 3 & 2 & 8 & 7 \\
\hline Totals. & 96 & 122 & 33 & 45 & 10 & 7 & 24 & 33 \\
\hline
\end{tabular}


Among these 370 moths there are recorded 218 sooty, 78 type, 17 sooty black, and 57 black. There are 296 gray to 74 black, showing slight deficiency of black, the expectation being 277.5 to 92.5. Among the gray the proportion, 218 sooty to 78 type, is very close to expectation, 222 to 74 . Among the black however, the ratio is reversed, there being 17 sooty black to 57 black. Apparently black reverses the dominance of sooty. On the basis of this reversal the expectation is 18.5 to 55.5 , very close to the numbers actually obtained. Certain black moths have the sooty base appearing as a 'ghost pattern.' This is the heterozygous condition, sS. The moth shown in figure $o$ is of this character. It is impossible to separate these from other blacks with any accuracy, but easy to distinguish the homozygote, SS, since the factor $\mathrm{S}$ not only blackens the base and outer margins of the wings, but also suppresses pigment in the intermediate area. In the duplex condition of the factor this supression is strong enough to affect the black pigment of the bb moth, as in figure $p$.

A sooty black male of this type, SS.bb, was paired (127) with a type female, ss.BB. There were produced 190 sooty, 80 males and 110 females. Cultures were made from these sooty as shown in table 2.

TABLE 2

\begin{tabular}{|c|c|c|c|c|c|c|c|c|}
\hline \multirow{3}{*}{$\begin{array}{l}\text { COMPOSITION } \\
\text { OF CELTURE }\end{array}$} & \multicolumn{8}{|c|}{ OFFSPRING } \\
\hline & \multicolumn{2}{|c|}{ Sooty } & \multicolumn{2}{|c|}{ Type } & \multicolumn{2}{|c|}{ Sooty black } & \multicolumn{2}{|c|}{ Black } \\
\hline & $a^{7}$ & $q$ & $\sigma^{\pi}$ & 웅 & $\sigma^{\pi}$ & q & $\sigma^{\pi}$ & $q$ \\
\hline $10^{7} \times 1$ 웅 & 22 & 23 & 9 & 8 & 1 & 1 & 9 & 7 \\
\hline $1 \sigma^{7} \times 1 \%$ & 12 & 19 & 6 & 3 & 5 & 2 & 5 & 7 \\
\hline $10 \times 1 \%$ & 43 & 39 & 26 & 15 & 2 & 2 & 16 & 24 \\
\hline $10^{7} \times 1 \%$ & 36 & 39 & 13 & 18 & 2 & 5 & 9 & 9 \\
\hline $10^{3} \times 1$ \% & 25 & 28 & 13 & 12 & 5 & 1 & 11 & 12 \\
\hline $10^{7} \times 4$ 웅 운 & 124 & 107 & 43 & 38 & 13 & 13 & 26 & 33 \\
\hline $20^{x} 0^{x} \times 1 \%$ & 30 & 37 & 14 & 12 & 6 & 0 & 8 & 8 \\
\hline $10^{\pi} \times 29$ 우 & 80 & 90 & 31 & 30 & 11 & 10 & 20 & 18 \\
\hline $20^{7} 0^{7} \times 3$ 우 & 88 & 97 & 29 & 28 & 9 & 8 & 26 & 25 \\
\hline $10^{7} \times 1 \%$ & 18 & 13 & 9 & 14 & 1 & 1 & 5 & 8 \\
\hline $10^{7} \times 19$ & 12 & 2 & 1 & 1 & 0 & 1 & 0 & 0 \\
\hline $10^{7} \times 1$ 웅 & 21 & 20 & 6 & 1 & 3 & 0 & 3 & 4 \\
\hline $10^{7} \times 1 \%$ & 19 & 20 & 8 & 10 & 1 & 0 & 2 & 12 \\
\hline Totals... & 530 & 534 & 208 & 190 & 89 & 44 & 140 & 167 \\
\hline
\end{tabular}


Among the 1873 moths there recorded, are 1064 sooty, 398 type, 103 sooty black, and 307 black. There are 1463 gray to 410 black, showing a slight deficiency of black, the expectation being 1405 to 468 . Among the gray the proportion, 1064 sooty to 399 type, shows a slight excess of type, the expectation being 1097 to 366. Among the black the ratio, 103 sooty black to 307 black, is remarkably close to 102.5 to 307.5 , the expectation with a reversal of dominance.

Summarizing the $\mathrm{F}_{2}$ generations from pair (125) (SS.BB $0^{7} \times$ ss.bb o) and pair (127) (SS.bb on $\times$ ss.BB o), we have 1282 sooty, 477 type, 120 sooty black, and 364 black, where the expectation on a $9: 3: 1: 3$ basis is $1261.8: 420.6: 140.2: 420.6$. The divergence from the expected ratio is largely due to the deficiency of black. There are in all 1759 gray to 484 black, the expectation being 1682 to 561. Considering the gray alone, there are 1282 sooty to 477 type, the expectation being 1319 to 440. Considering the black alone, there are 120 sooty black to 364 black, the expectation being 121 to 363 .

A convenient method of expressing dominance in a reversal of this sort is to reverse the relative positions of the symbols placing the small letter before the large. In writing the formula of a phenotype alternative possibilities may be expressed by symbols in parentheses. Thus a moth typical in appearance would be either ss.BB or ss.Bb, expressed ss.BB(b): a sooty would be $\mathrm{SS}(\mathrm{s}) \cdot \mathrm{BB}(\mathrm{b})$ : a sooty black would necessarily be homozygous, SS.bb: and a black would be ss(S).bb.

Pairings were made of moths from the $\mathrm{F}_{2}$ or segregating generations from matings (125) and (127). The genetic composition of these moths must be inferred from their appearance and the character of the fraternities produced. The results are of interest, since they corroborate conclusions concerning the heredity of sooty and black.

Each of four pairs of sooty by sooty produred only. sooty, 246 in all, showing that each pair must have been $\mathrm{SS} \times \mathrm{SS}(\mathrm{s})$ and $\mathrm{BB} \times \mathrm{BB}(\mathrm{b})$.

Each of four pairs of sooty by sooty black produced only sooty, 275 in all, showing that each pair must have been $\mathrm{SS}(\mathrm{s}) . \mathrm{BB} \times \mathrm{SS} . \mathrm{bb}$. 
Two pairs of sooty by sooty black produced 46 sooty and 50 sooty black, showing that each pair must have been SS.Bb $\times$ SS.bb.

A pair of sooty produced 56 sooty and 21 sooty black, showing that each parent was SS.Bb.

A sooty black male paired with a black female produced 58 black, showing that the pair was SS.bb $\times$ ss.bb. The black progeny, sS.bb showed sooty indistinctly as a 'ghost pattern.'

Two pairs of sooty by sooty produced 29 sooty, 12 type, 1 sooty black, and 10 black. Since sooty, type, and black were produced from each mating, the parents must have been $\mathrm{Ss.Bb}$.

A black male paired with a sooty female produced 6 sooty, 7 type, 3 sooty black, and 4 black. Since both type and sooty black were produced the parents must have been sS.bb and Ss.Bb. The theoretical ratio would be 3 sooty ( $1 \mathrm{SS} . \mathrm{Bb}$ and $2 \mathrm{Ss.Bb}$ ), 1 type (ss.Bb), 1 sooty black (SS.bb), 3 black ( 2 sS.bb and 1 ss.bb).

A sooty male paired with a type female produced 26 sooty, 33 type, and 30 black. Since both type and black were produced, the parents must have been Ss.Bb and ss.Bb. The theoretical ratio would be 3 sooty ( $1 \mathrm{Ss.BB}$ and $2 \mathrm{Ss.Bb}$ ), 3 type (1 ss.BB and $2 \mathrm{SS} . \mathrm{Bb}$ ), and 2 black ( 1 sS.bb and 1 ss.bb). The expected ratio is 33 sooty, 33 type, and 22 black.

A sooty male paired with a black female produced 32 sooty, 16 sooty black, and 20 black. Since no type were produced, the male parent must have been homozygous for sooty, and since sooty black were produced, both parents must have carried sooty. The cross was therefore SS.Bb $\times$ sS.bb. The theoretical ratio would be 2 sooty ( $\mathrm{SS} . \mathrm{Bb}$ and $\mathrm{Ss.Bb}$ ), 1 sooty black (SS.bb), and 1 black (sS.bb). The expected ratio is 34 sooty, 17 sooty black, and 17 black, to which the actual numbers although small are very close.

A pair, sooty male by sooty black female, and two pairs, sooty black males by sooty females, produced 66 sooty, 42 sooty black, and 16 black. Since black were produced, the sooty parents were Ss.Bb. The sooty black parents would of course be SS.bb. 
This would give a theoretical ratio of 2 sooty (SS.Bb and Ss.Bb), 1 sooty black (SS.bb), and 1 black (sS.bb). The expected ratio is 62 sooty, 31 sooty black, and 31 black.

\section{SUMMARY AND GENERAL DISCUSSION}

Genetic work on the Mediterranean flour-moth has been handicapped by low fertility of the pairs, due for the most part to failure of females to oviposit.

Variations in size are apparently not hereditary.

Variations in length and divergence of leg spines, as well as abnormalities in external male genitalia, have not been tested genetically.

Defects in the labial palpi are hereditary but very irregular in appearance and probably much affected by environment.

The heredity of color variations and of cleft tongue will be discussed below.

\section{A. The masking of a Mendelian difference by environment}

It has for some time been recognized that the failure of a genetic character difference to appear is not necessarily due to the absence from the germ-plasm of the genetic factor or factors involved.

Baur ('11) has shown that in Primula sinensis both a genetic factor and certain environmental conditions are necessary for the production of pigment, and in Drosophila Morgan ('15) has demonstrated this for production of abnormal abdomen and Hoge ('15) for supernumerary legs.

In moths with cleft tongue, maxillae fail to unite for a variable part of their length. This abnormality apparently depends for its expression on certain environmental conditions, among which humidity is important. The hereditary basis may be a single factor difference from the normal, but further work will be necessary in order to demonstrate this conclusively. 


\section{B. Reversal of dominance}

Reversal of dominance by sex has been called sex-limitation by Morgan ('14). This phenomenon has been demonstrated for horns in sheep by Wood ('05), for supernumerary mammae in swine ('12), and color in Ayrshire cattle ('16) by Wentworth, and for color in the butterfly, Colias philodice, by Gerould ('11).

Variations in dominance are frequent and are due to environment, age, or genetic constitution.

The present studies show a perfectly clear case of reversed dominance due to a simple Mendelian difference. Sooty is a simple dominant to type, while black is a simple recessive. In the homozygous black moths, however, sooty acts as a recessive. The dihybrid ratio, therefore, approximates 9 sooty, 3 type, 1 sooty black, and 3 black. Other ratios are discussed in the text, and it is suggested that reversal of this sort may be expressed by reversing the symbols denoting the factors. Thus heterozygous sooty is Ss.BB while heterozygous sooty black is sS.bb. A possible explanation for the reversal of dominance in this case is suggested under the discussion of the physiology of color production.

\section{Analysis of a case of continuous variation}

The separation of sooty base from type was at first impossible, as moths in single fraternities varied continuously from the most pronounced sooty to undoubted type. In later generations the segregation became sharp in some fraternities, but in others the intergradation persisted. A hereditary variation which darkened slightly the base of the wings, thus showing a slight tendency towards sooty, was probably responsible for some of the confusion. By far the greatest difficulty, however, resulted from the variation known as dark mid-area or dark. This variation has an effect somewhat the reverse of sooty base. It shows much intergradation with type, but probably depends upon a simple Mendelian difference. The nature of the reverse effect of sooty and dark is further discussed in the following section. 


\section{The physiology of color production}

As regards coloration of the upper side of the fore-wing there is striking symmetry of the proximal to the distal half. In the type moth there are black marks near the center. The gray midarea is bounded distally and proximally by outer and inner transverse, wavy, black lines. Next to these are the outer and inner narrow whitish lines and then the gray marginal and basal areas. At extreme margin and base are small black marks. In the color variations studied, symmetry is not lost, although certain of the markings mentioned are obliterated by intensifcation or dilution of pigment.

Color variations may be supposed to depend upon relative variations in quantity of a color producer and a color inhibitor. Figure 1 expresses the genetic and physiological relationships of color production in the proximal half of the fore-wing. The conditions in the distal half would be shown by a diagram symmetrical to this. Passing from left to right are shown as labeled the conditions at extreme base, basal area, inner white line, inner black line, inner half of mid-area, and inner half of median spots. The solid heavy curved line labeled $C$ expresses the quantity of color producer present in the various regions of the wing. It is probable that this is not a single substance, but rather a color base and an activating enzyme. The color base may be present in greatest amount at extreme base of wing, black line, and median spots and in least amount in white line. The enzyme may decrease constantly in amount towards center of wing. The combination of the curves representing quantities of base and enzyme would approximate the curve $C$.

The other curves express relative quantity of inhibitor in each region for each of the color varieties studied. All of these curves are of exactly the same form and each is symmetrical with relation to a line drawn through the similarly labeled point in the ruled rectangle and at an angle of $45^{\circ}$ to the horizontal. The curves would therefore coincide where the points superposed. The displacement of these points relative to each other represents, therefore, the displacement of the curves. 




Fig. 1 
Neither the forms of the curves nor the displacements of the points are to be taken as in any way exact. They are merely approximations which express the genetic and apparent physiological relationships involved.

Curve and point $T$ show amount of inhibitor in the type moth. The colors of the regions of the wing are printed below in the line marked $T$. Dots, curves, and colors of regions are correspondingly labeled for the other color varieties. The regions of the wings are not, of course, marked off definitely as expressed by the perpendicular lines, but grade into each other more or less as shown by the curves.

The recessive variation, black, (b), is represented as a general lowering of the inhibitor. Its point is placed four squares directly below that for type and its curve is correspondingly an equal distance below the type curve. Black, therefore, inhibits pigment formation only in the white lines. Variation in this respect obtains among individuals of black cultures. The moth represented in figure $o$ has only a trace of the white lines.

The variation, dark mid-area, (d), darkens mid-area and lightens base. Its point is placed one square below and to the right of type. Its curve then is somewhat below that for the color producer in the mid-area and slightly above it towards the base. Dark black has its point and curve four points below dark. It may be seen to bear the same relation to black that dark does to type. A comparison of the curves of black and dark black shows how the 'ghost pattern' of dark seen in dark black is formed. The greater distance from the color producer curve of the curve for dark black at mid-area and the lesser distance towards the base accounts for the greater intensity of the mid-area.

There is, as stated, much intergradation with type in the dark mid-area moths. The points and curves shown in the diagram represent only one grade.

Sooty base has an action somewhat reverse to dark mid-area. Heterozygous sooty $\left(\mathrm{S}_{1}\right)$ has its point two squares above and three squares to the left of type and homozygous sooty $\left(\mathrm{S}_{2}\right)$ has its point twice that distance from type. This brings the curves 
above the developer in mid-area and below towards base. They cross the curve for color producer at almost the same point and are each at sufficient distance above or below to indicate considerable dilution or intensification of pigment. Hence there is almost complete dominance of sooty despite the fundamental physiological difference between homozygote and heterozygote as expressed by the distances between their points and between their curves.

This fundamental difference is revealed in the reversal of domiance produced by black. It will be noticed that the points for sooty black are four points below the corresponding points for sooty. Black heterozygous for sooty $\left(\mathrm{S}_{1} b\right)$ therefore has its curve entirely below the developer curve, except at the white line, while the curve for homozygous sooty black $\left(\mathrm{S}_{2} \mathrm{~b}\right)$ closely approaches the developer curve in the mid-area, thus producing dilution of pigment. The difference in the course of the curve for black heterozygous for sooty from the curve for black accounts for the 'ghost pattern,' which is as expected the reverse of that seen in dark black.

The explanation here suggested for the reversal of dominance shows that while black acts as a dominant over sooty black, it is really an 'absence,' a lack of something possessed by sooty black. Let it not be supposed that this has anything to do with the much discussed 'presence-absence' theory. We are here dealing with physiological phenomena which are correlated with genetic factors. The greater amount of inhibitor in gray moths corresponds with the presence of the factor for gray and the absence of the factor for black, while the lesser amount in black moths corresponds with the presence of the factor for black and the absence of the factor for gray.

Curves corresponding with sooty dark are not shown. The effect of dark upon sooty is obvious, since the points for the two move in opposite directions from type.

The hypothesis advanced here to explain color production might be modified so that certain of the factors should affect the concentration of the activating enzyme rather than that of the inhibitor. In this case the displacement of the enzyme 
curves would of course be in the opposite direction from that assumed for the inhibitor curves.

While the curves for inhibitors have all been drawn for convenience to the same form, it is obvious that the facts are in agreement with the supposition that the curves represent waves of slightly different lengths. In general the crests are at base and outer margin, while the troughs are in line with the median spots. Dark shortens the wave, making the trough slightly deeper. Sooty lengthens the wave considerably, making the trough shallower. Black merely reduces quantitatively without changing the form.

Changes in length of waves may be compared to the effect of the different factors in the banding series in cats (Whiting, '18). Bands of three different widths as seen in tabby cats are determined by three factors apparently allelomorphic. The narrower bands are dominant over the wider. It seems probable that in this case the bands represent waves of varying metabolic activity rather than concentration of definite enzymes or inhibitors.

Change in quantity of inhibitor without change of form of waves may be compared to agouti series in mammals. Individual hairs show bands of yellow more or less wide according to the quantity of inhibitor for black present. It is probable that the length of waves of concentration is not modified. 


\section{LITERATURE CITED}

BanKs, Nathan Bibliographies of the more important contributions to American economic entomology. U. S. Dept. of Agriculture, Bureau of Entomology.

BAUR, Erwin 1911 Einführung in die experimentelle Vererbungslehre. Borntraeger. Berlin.

Gerovud, J. H. 1911 The inheritance of polymorphism and sex in Colias philodice. Amer. Nat., vol, 45.

Hoge, M. A. 1915 The influence of temperature on the development of a Mendelian character. Jour. Exp. Zoöl., vol. 18.

Morgan, T. H. 1914 Sex-limited and sex-linked inheritance. Amer. Nat,, vol. 48.

1915 The rôle of the environment in the realization of a sex-linked Mendelian character in Drosophila. Amer. Nat., vol. 49.

Ormerod, Eleanor A. 1889 Note on page 315, Insect Life, vol. 1, p. 10.

Riley, C. V. 1889 The somealled Mediterranean flour-moth. Insect Life, vol. 2 , p. 6 .

Wentworth, E. N. 1912 Another sex-limited character. Science, N. S., vol. 35 , no. 913 .

1916 A sex-limited color in Ayrshire cattle. Jour. Agric. Research, vol. 6 .

Whrtina, P. W. 1918 Inheritance of coat-color in cats. Jour. Exp. Zoöl., vol. 25.

Woon, T. B. 1905 Note on the inheritance of horns and face color in sheep. Jour. Agric. Sci., vol. 1, pt. 3.

Zelcer 1879 Ephestia kühniella n. sp. Stettiner entomologische Zeitung., Bd. 40. 


\section{PLATE 1}

\section{EXPLANATION OF FIGURES}

$a$ Oblique view of head showing median palpus and tongue with coil pushed to the side.

$b$ Side view of tip of male abdomen.

$c$ Side view of head of type moth, showing tongue partially uneoiled.

d Oblique view showing tongue uncoiled and palpi asymmetrical.

$e$ Side view of tip of female abdomen.

$f$ Side view of head of black moth, with normal mouth parts.

$g$ Ventral view, palpi very small, tongue cleft to base with elements diverging laterally.

$h$ Side view showing tongue uncoiled and partially cleft.

$i$ Ventral view, pupal cap retained, tongue cleft to base and elements coiled at sides.

$j$ Side view of head of black tongueless moth.

k. Ventral view of head of black tongueless moth.

$l$ Side view showing tongue uncoiled and palpi short. 
P. W. WHITING
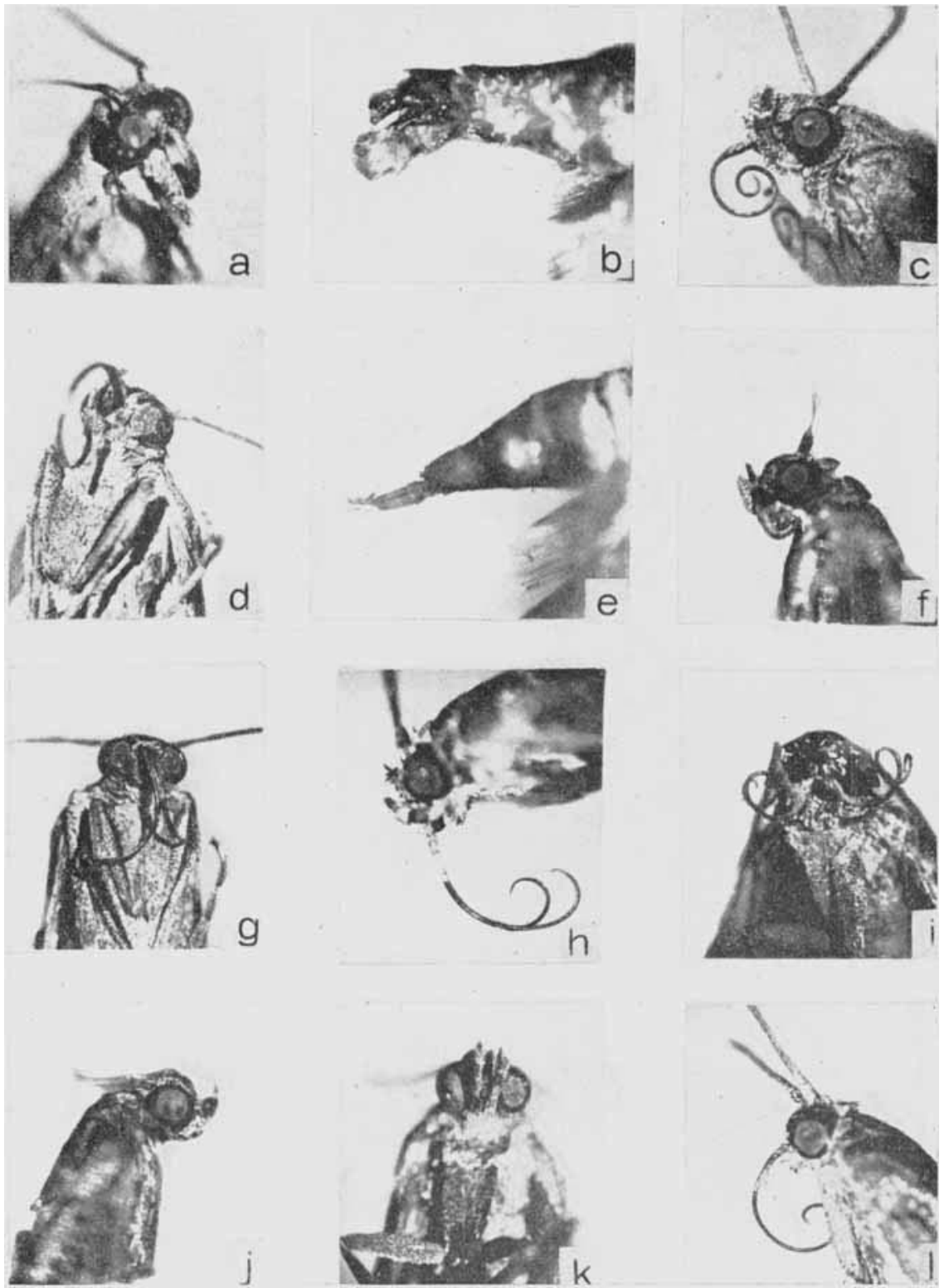
PLATE 2

EXPLANATION OF WIGURES

$m$ Type moth, ss. BB (b).

$n$ Sooty-base moth, SS (s), BB (b).

o Black moth, ss (S). bb.

$p$ Sooty black moth, SS. bb. 
P. W, WHITING

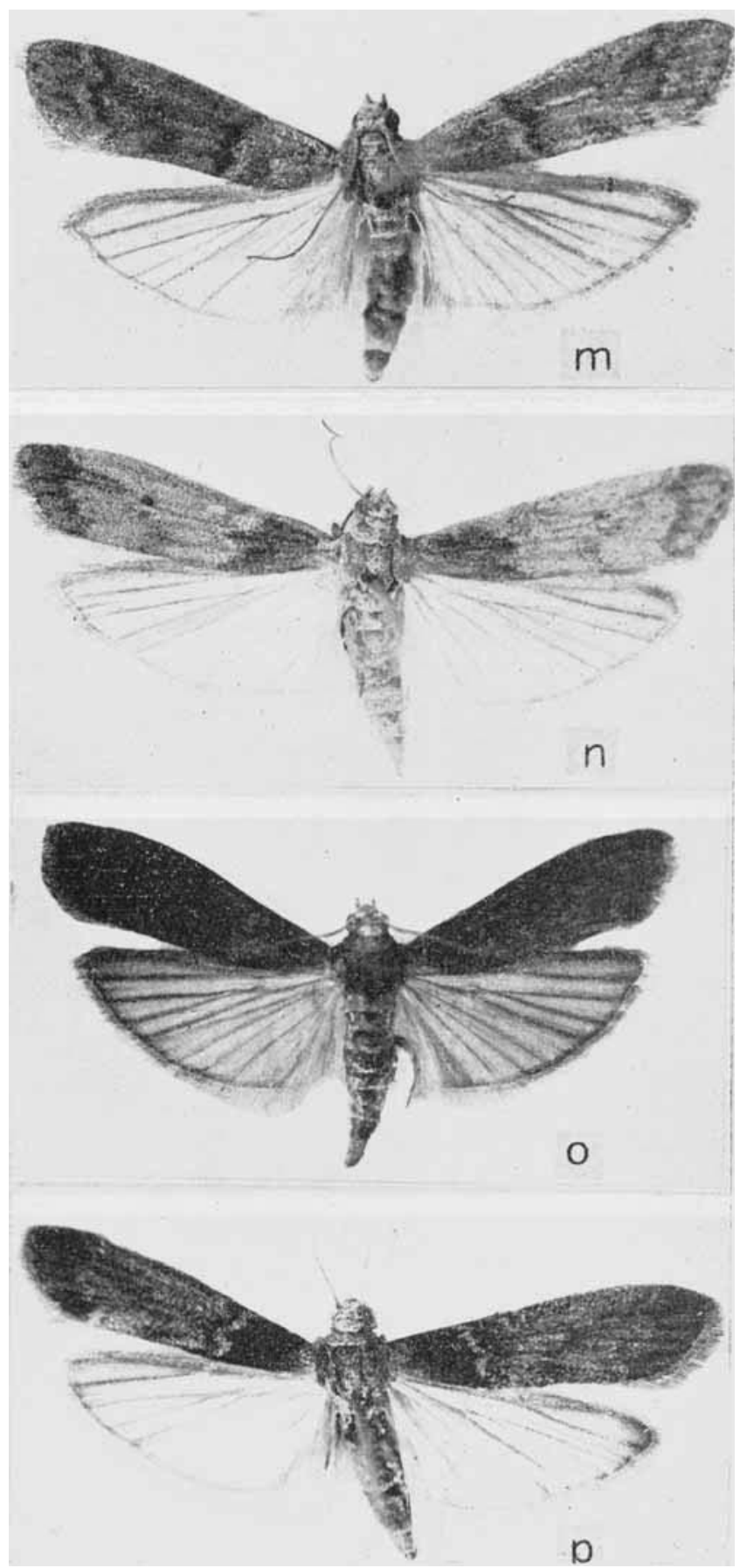

